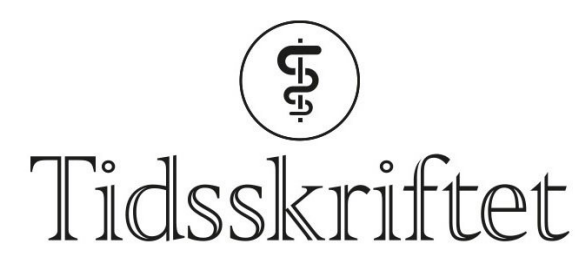

DEN NORSKE LEGEFORENING

\title{
Jarle Tor Rørvik
}

MINNEORD

KJELL-MORTEN MYHR

JORUNN SKEI

ODD HELGE GILJA

LEIV HOVE

NILS ERIK GILHUS

og

PER BAKKE

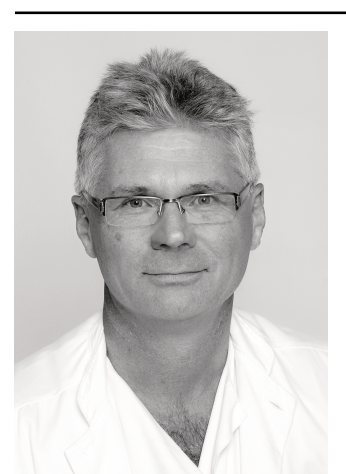

Jarle Tor Rørvik (1954-2018) ble født på Vigra og flyttet i skoleårene til Volda. Som student flyttet han videre til Bergen og avla medisinsk embetseksamen ved Universitet i Bergen i 1981. Etter turnustjeneste og klinisk arbeid begynte han i 1986 med spesialisering i radiologi, og i over zo år jobbet han som røntgenlege ved Haukeland universitetssykehus. Parallelt med klinisk arbeid hadde Jarle også et stort engasjement for forskning og undervisning. Han disputerte i 1998 med avhandlingen On staging of prostate cancer prior to radical treatment. I 2008 ble han ansatt som professor I i radiologi ved Universitet i Bergen, og siden hadde han hovedansvaret for forskning og undervisning i radiologi ved sykehuset og universitetet. I 2013 ble Jarle seksjonsleder for radiologi og leder for undervisning ved Klinisk institutt 1, Universitetet i Bergen, og siden 2014 ledet han også Bergen Abdominal Imaging Research Group.

Jarle var en kunnskapsrik og entusiastisk kollega og en foregangsmann for brobygging og samarbeid på tvers av profesjoner og institusjoner. Han hadde derfor en naturlig nøkkelrolle i utviklingen av MedViz og var styreformann 2010-17. I sitt arbeid konsentrerte 
han seg særlig om radiologisk fagutvikling og forskning innen uroradiologi, som var hans spesialfelt.

Jarle hadde et stort engasjement for undervisning av medisinstudenter. I utviklingen av undervisningsmetoder innen sitt eget fagfelt var han en pioner, og han ble prisbelønnet for dette. I tillegg var han også en utrettelig pådriver for å utvikle samarbeidet mellom sykehuset og universitetet i undervisningen av både studenter og legespesialister. I dette arbeidet utmerket Jarle seg gjennom sin varme og joviale væremåte. Han hadde alltid stort fokus på fag og undervisning - men kunne lett snakke om det meste - ofte om tur og hytteliv på fjellet og familie. Han snakket uanstrengt med alle og var en inspirator og et klokt og omsorgsfullt medmenneske som vil bli dypt savnet.

Også nasjonalt markerte Jarle seg, gjennom verv i Norsk radiologisk forening, Norsk forening for abdominal radiologi og i etableringen av Radforsk - Norsk Radiologisk Forskningsinstitutt. Han hadde i tillegg et stort internasjonalt engasjement gjennom europeiske forskernettverk og aktivt medlemskap i Europeisk selskap for urogenital radiologi.

Det er med stor sorg vi mottok beskjeden om Jarle Tor Rørviks plutselige bortgang, og han etterlater seg et stort tomrom. Vi minnes ham i stor takknemlighet. For oss var han en varm kollega, engasjert og kunnskapsrik fagperson og en god venn. Våre tanker går til hans mange venner og kolleger og særlig til Jarles familie, hans kone Tove og hans tre barn Håvard, Eivind og Synne med familier som har mistet en kjær ektefelle, far, svigerfar og bestefar.

På vegne av kolleger ved Klinisk institutt 1 og Det medisinske fakultet, Universitetet $i$ Bergen

Publisert: 8. mai 2018. Tidsskr Nor Legeforen. DOI:10.4045/tidsskr.18.026o

(C) Tidsskrift for Den norske legeforening 2020. Lastet ned fra tidsskriftet.no 